\title{
Effect of Gamma Radiation on Reproductive Performance of Silkworm (Bombyx mori L.) female uzi flies Exorista bombycis (Louis)
}

\author{
K. Vasudha Prabhakar, G. V. Vishaka and T. K. Narayanaswamy* \\ Department of Sericulture, University of Agricultural Sciences, GKVK, \\ Bangalore-65, Karnataka, India \\ *Corresponding author
}

\section{A B S T R A C T}

\begin{tabular}{|l|}
\hline Ke y w or d s \\
$\begin{array}{l}\text { Female pupae, } \\
\text { eggs laid, irradiated } \\
\text { pupae, sterility, } \\
\text { hatching } \\
\text { percentage, } \\
\text { fertility, fecundity }\end{array}$ \\
\hline Article Info \\
\hline $\begin{array}{l}\text { Accepted: } \\
\text { 30 October } 2017 \\
\text { Available Online: } \\
\text { 10 December } 2017\end{array}$ \\
\hline
\end{tabular}

The different aged female uzi flies pupae of 6,7 and 8 day old were selected and irradiated at $1,1.5$ and $2 \mathrm{kr}$ gamma irradiation. The fecundity (No.), fertility (No.) and hatching percentage $(\%)$ was recorded in female flies which emerged out of irradiated pupae. The female uzi flies that emerged from 6,7 and 8 day old irradiated pupae at $1.0 \mathrm{Kr}$ mated with normal male uzi flies showed fertility of $66.66,68.33$ and 467.00 . Whereas, the female flies that emerged out 7 and 8 day old irradiated pupae at $1.5 \mathrm{Kr}$ showed fertility of 20.00 and 110.00. However, the female flies that emerged out of 8 day old irradiated pupae at 2.0 $\mathrm{Kr}$ showed 165.33 fertility. The hatching percentage of $13.54,13.81$ and 94.71 was recorded in the female flies which emerged from the 6,7 and 8 day old irradiated pupae at $1 \mathrm{kr}$. The percent of hatching was 5.00 and 82.70 in the eggs laid by the female flies which emerged from 7 and 8 day old irradiated pupae at $1.5 \mathrm{kr}$. The hatching percentage of 88.34 was observed at $2 \mathrm{kr}$ radiation in female flies that emerged from 8 day old irradiated pupae.

\section{Introduction}

The mulberry silkworm, Bombyx mori L. is one of the important productive insects reared indoors and exploited for silk of commerce. Sericulture is considered as an income generating occupation in rural areas. The sericigenous insects are not an exception from attack of parasitoids, predators and pathogens. Control of this pest through insecticidal treatment is not feasible due to its adverse consequences on the growth and development of silkworm.

The practical applicability of radiationinduced sterile insect release method has been suggested earlier by several scientists.
The efficacy of gamma radiation varies according to insect species, the stage of the insect subjected to radiation and the dose of radiation.

In view of the importance of E. bombycis as a serious pest of Bombyx mori and the role of gamma irradiation in control, studies were taken to know the effect of gamma radiation on various bioresponses of $E$. bombycis male flies in curtailing uzi fly population in the field conditions. In this study an attempt was made to known the effect of gamma radiation on female uzi flies and their reproductive performance. 


\section{Materials and Methods}

The present study was conducted at Department of Sericulture, University of Agricultural Sciences, Bengaluru-65. The uzi fly maggots were collected from the cocoon markets (viz., Shidlaghatta / Vijayapura, Chickballapuara district) in plastic containers with perforated lids. In the laboratory, sand bed with dark condition was provided for uzi fly maggots to undergo pupation for further laboratory studies.

\section{Source and dose of gamma radiation}

Separation of samples of 6,7 and 8 day old male uzi pupae (sex was done based on the size and weight of pupae) collected from the laboratory culture were irradiated using a ${ }^{60} \mathrm{C}$ source (gamma radiation), model BI 2000, at the facility available at National Centre for Biological Sciences (NCBS), GKVK Campus, Bengaluru. The gamma radiation was given at doses of $1,1.5$ and $2 \mathrm{kr}$ to the pupae. Three replications were maintained for each dosage, with 50 pupae constituting each replication, along with control with different aged pupae. During the irradiation process, the pupae to be treated were kept in plastic containers with lid. The electronic dose measuring unit attached to the machine recorded the dosage delivered to each batch, which was further noted down. The treated batches of pupae were confined in separate rearing cages and utilized for further studies to record the following observations.

\section{Fecundity (Number/Individual)}

The female uzi fly emerged from irradiated pupae was introduced into the cage for oviposition the silkworms were daily replaced by a fresh batch of 50 worms to record the fecundity of the fly, the total number of eggs laid by the single fly was counted and the average fecundity was calculated.

\section{Fertility (Number)}

The fertility was calculated based on the number of scars developed out of number of eggs laid.

\section{Hatchability (\%)}

The eggs laid by female uzi fly attached to silkworm body and the black scar formed on the silkworms were counted to record the number of eggs hatched.

The hatching percentage was calculated by using the following formula

Hatchability $=\frac{\text { No. of eggs hatched }}{\text { No. of eggs laid }}$

\section{Results and Discussion}

\section{Fecundity}

The number of eggs laid was 491.00, 494.00 and 493.00 in female uzi flies mated with normal males that emerged from 6,7 and 8 day old irradiated pupae at $1 \mathrm{kr}$. Whereas, the flies that emerged out of 7 and 8 day old irradiated pupae at $1.5 \mathrm{kr}$ resulted in 420.0 and 133.33 number of eggs at $1.5 \mathrm{kr}$.

However, the female uzi flies emerged out of 8 day old irradiated pupaeat $2.0 \mathrm{kr}$ showed 187.21 fecundity at $2 \mathrm{kr}$. The number of eggs laid by the female uzi flies which emerged from the irradiated pupae of 6,7 and 8 day, mated with normal males showed same number of eggs laid by female mated with normal female flies. This showed that gamma radiation at 1 krnot exhibited any effect on the female uzi flies fecundity (Table 1). These results are in conformity with Fatima (1994) who opined that mean number of eggs laid by a single normal gravid uzi fly was 501 and the range was from 305- 731 . 
Table.1 Fecundity of female flies emerged from irradiated pupae mated with normal male uzi flies (No.)

\begin{tabular}{|c|c|c|c|c|}
\hline \multirow{2}{*}{$\begin{array}{c}\text { Radiation } \\
(\mathbf{k r})\end{array}$} & \multicolumn{3}{|c|}{ Age of pupae (days) } & \multirow{2}{*}{ Average } \\
\cline { 2 - 4 } & $\mathbf{6}$ & $\mathbf{7}$ & $\mathbf{8}$ & \multirow{2}{*}{$492.57^{\mathrm{d}}$} \\
\hline \multirow{2}{*}{1.0} & $\begin{array}{c}491.00 \\
(22.17)\end{array}$ & $\begin{array}{c}494.00 \\
(22.24)\end{array}$ & $\begin{array}{c}493.00 \\
(22.21)\end{array}$ & \multirow{2}{*}{$184.34^{\mathrm{b}}$} \\
\hline \multirow{2}{*}{1.5} & $\begin{array}{c}000.00 \\
(0.71)\end{array}$ & $\begin{array}{c}420.00 \\
(20.51)\end{array}$ & $\begin{array}{c}133.33 \\
(7.14)\end{array}$ & \multirow{2}{*}{$62.43^{\mathrm{a}}$} \\
\hline \multirow{2}{*}{2.0} & $\begin{array}{c}000.00 \\
(0.71)\end{array}$ & $\begin{array}{c}000.00 \\
(0.71)\end{array}$ & $\begin{array}{c}187.21 \\
(12.87)\end{array}$ & \multirow{2}{*}{$420.89^{\mathrm{c}}$} \\
\hline \multirow{2}{*}{ Control } & $\begin{array}{c}540.00 \\
(23.24)\end{array}$ & $\begin{array}{c}497.66 \\
(22.32)\end{array}$ & $\begin{array}{c}478.26 \\
(13.92)\end{array}$ & \\
\hline Average & $257.78^{\mathrm{a}}$ & $352.70^{\mathrm{b}}$ & $359.36^{\mathrm{c}}$ & \\
\hline
\end{tabular}

\begin{tabular}{|l|c|c|c|}
\hline & Radiation & Age of pupae & Radiation $\times$ age of pupae \\
\hline F-test & $*$ & $*$ & $*$ \\
\hline SEm \pm & 0.62 & 0.56 & 1.38 \\
\hline CD at $5 \%$ level & 1.74 & 1.59 & 3.99 \\
\hline
\end{tabular}

Note

1. Means followed by the same alphabet are not significantly different. 2. Figures in the parenthesis indicate

Transformed value (square root of $X+1 / 2$ ). 3. $n=50$ (fourth instar silkworm). 4. *Significant at $5 \%$ level.

Table.2 Fertility of female flies emerged from irradiated pupae mated with normal male uzi flies (No.)

\begin{tabular}{|c|c|c|c|c|}
\hline \multirow{2}{*}{ Radiation (Kr) } & \multicolumn{3}{|c|}{ Age of pupae (days) } & \multirow{2}{*}{ Average } \\
\hline & 6 & 7 & 8 & \\
\hline 1.0 & $\begin{array}{l}66.66 \\
(8.13)\end{array}$ & $\begin{array}{l}68.33 \\
(8.28)\end{array}$ & $\begin{array}{l}467.00 \\
(21.61)\end{array}$ & $200.46^{\mathrm{c}}$ \\
\hline 1.5 & $\begin{array}{l}00.00 \\
(0.71)\end{array}$ & $\begin{array}{l}20.00 \\
(3.06)\end{array}$ & $\begin{array}{l}110.00 \\
(6.56)\end{array}$ & $65.23^{\mathrm{b}}$ \\
\hline 2.0 & $\begin{array}{l}00.00 \\
(0.71)\end{array}$ & $\begin{array}{l}00.00 \\
(0.71)\end{array}$ & $\begin{array}{c}165.33 \\
(9.59)\end{array}$ & $55.11^{\mathrm{a}}$ \\
\hline Contr01 & $\begin{array}{l}525.00 \\
(22.91)\end{array}$ & $\begin{array}{l}479.33 \\
(21.91)\end{array}$ & $\begin{array}{l}465.00 \\
(22.03)\end{array}$ & $496.12^{d}$ \\
\hline Average & $147.85^{b}$ & $141.2^{\mathrm{a}}$ & $306.83^{c}$ & \\
\hline
\end{tabular}

\begin{tabular}{|c|c|c|c|}
\hline & Radiation & Age of pupae & Radiation $\times$ age of pupae \\
\hline F-test & $*$ & $*$ & $*$ \\
\hline SEm \pm & 0.51 & 1.67 & 0.98 \\
\hline CD at 5\% level & 1.68 & 4.35 & 3.23 \\
\hline
\end{tabular}

Note

1. Means followed by the same alphabet are not significantly different. 2. Figures in the parenthesis indicate Transformed value (square root of $X+1 / 2$ ). 3. $n=50$ (fourth instar silkworm). 4. *Significant at $5 \%$ level. 
Table.3 Hatching percentage of the female flies emerged from irradiated pupae mated with normal male uzi flies (\%)

\begin{tabular}{|c|c|c|c|c|}
\hline \multirow{2}{*}{$\begin{array}{l}\text { Radiation } \\
\text { (Kr) }\end{array}$} & \multicolumn{3}{|c|}{ Age of pupae (days) } & \multirow{2}{*}{ Average } \\
\hline & 6 & 7 & 8 & \\
\hline $1 \mathrm{kr}$ & $\begin{array}{l}13.54 \\
(3.72)\end{array}$ & $\begin{array}{l}13.81 \\
(3.77)\end{array}$ & $\begin{array}{l}94.71 \\
(9.76)\end{array}$ & $40.62^{c}$ \\
\hline $1.5 \mathrm{kr}$ & $\begin{array}{c}00.00 \\
(0.707)\end{array}$ & $\begin{array}{c}05.00 \\
(1.783)\end{array}$ & $\begin{array}{c}82.70 \\
(9.539)\end{array}$ & $32.56^{\mathrm{b}}$ \\
\hline $2 \mathrm{kr}$ & $\begin{array}{l}00.00 \\
(0.71)\end{array}$ & $\begin{array}{l}00.00 \\
(0.71)\end{array}$ & $\begin{array}{l}88.34 \\
(9.68)\end{array}$ & $29.54^{\mathrm{a}}$ \\
\hline Control & $\begin{array}{l}97.12 \\
(9.98)\end{array}$ & $\begin{array}{l}96.25 \\
(9.76)\end{array}$ & $\begin{array}{l}97.20 \\
(9.98)\end{array}$ & $96.75^{d}$ \\
\hline Average & $27.63^{\mathrm{a}}$ & $28.76^{a}$ & $90.73^{b}$ & \\
\hline
\end{tabular}

\begin{tabular}{|c|c|c|c|}
\hline & Radiation & Age of pupae & Radiation $\times$ age of pupae \\
\hline F-test & $*$ & $*$ & $*$ \\
\hline SEm \pm & 0.71 & 2.07 & 1.99 \\
\hline CD at 5 \% level & 2.68 & 5.15 & 4.23 \\
\hline
\end{tabular}

Note

1. Means followed by the same alphabet are not significantly different. 2 . Figures in the parenthesis indicate

Transformed value (square root of $\mathrm{X}+1 / 2$ ). 3. $\mathrm{n}=50$ (fourth instar silkworm). 4. *Significant at 5\% level.

\section{Fertility and hatching}

The female uzi flies that emerged from 6,7 and 8 day old irradiated pupae at $1.0 \mathrm{kr}$ mated with normal male uzifies showed fertility of 66.66, 68.33 and 467.00. Whereas, the female flies that emerged from 7 and 8 day old pupae showed hatching percentage of 05.00 and 82.70 at $1.5 \mathrm{kr}$. However, the female uzi flies that emerged out of 8 day old pupae showed 165.33 fertility at $2 \mathrm{kr}$ (Table 2). The number of eggs that hatched were 13.54, 13.81 and 94.71 out of eggs laid by the female uzi flies which emerged from the 6,7 and 8 day old irradiated pupae at $1 \mathrm{kr}$. The hatching percentage of $88.34 \%$ was observed at $2 \mathrm{kr}$ radiation in female flies that emerged from 8 day old irradiated pupae. This showed that 1.5 kr gamma radiations on 7and 8day old female pupae is capable of inducing sterility in female uzi flies (Table 3). These results differ with katiyar et al., (2007) who stated that a minimum dose of $2 \mathrm{kr}$ was sufficient to inhibit fertility in 5 and 6 day old pupae. This may be due to non-usage of 1 and $1.5 \mathrm{kr}$ of doses.

\section{Acknowledgement}

I am thankful to UGC, New Delhi, for providing financial assistance, required support and facility for the project Entitled, "Induction of male sterility in silkworm uzi fly, Exorista bombycis (Louis) - A parasitoid of silkworm, Bombyx mori L."

\section{References}

BONTHA KASI REDDY AND JEMMY VENKATA KRISHNA RAO, 2009, Seasonal occurrence and control of silkworm diseases, grasserie, flacherie and muscardine and insect pest, uzi fly in Andhra Pradesh, India. Int. J. Indust. Entomol, 18(2):57-61.

FATIMA, S., 1994, Reproductive biology of 
the Indian uji fly, Exorista bombycis (Louis) and the effect of light energy in its management. Ph.D. Thesis, UAS, Bangalore, p.143.

KATIYAR, R. L., MANJUNATH, D., SATHYA PRASAD, K., RAM KISHORE AND DATTA, R.K., 2007, Induction of sterility in the uzi fly, Exorista bombycis (Louis) through gamma irradiation, Uttar Pradesh. $J$. Zool., 27 (3):271-278.

KUMAR VINOD, SINGH AMARDEV AND MALHOTRA KIRAN, 2012, Mass production of Tetrastichushawardii on house fly a pupal parasitoid of leaf roller- A pest of mulberry plant. International research Journal of Biological Sciences, 1 (8):36-39.

\section{How to cite this article:}

Vasudha Prabhakar K., G. V. Vishaka and Narayanaswamy T. K. 2017. Effect of Gamma Radiation on Reproductive Performance of Silkworm (Bombyx mori L.) female uzi flies Exorista bombycis (Louis). Int.J.Curr.Microbiol.App.Sci. 6(12): 5416-5420. doi: https://doi.org/10.20546/ijcmas.2017.612.506 